\title{
KONSTRUKSI PEMBERITAAN PILKADA SERENTAK 9 DESEMBER 2015 PADA CNNINDONESIA.COM
}

\author{
Finy F. Basarah \\ finy_fb@yahoo.com \\ Fakultas Ilmu Komunikasi Universitas Mercu Buana
}

\begin{abstract}
The Indonesian Simultaneous Local Elections would be held in Dec 9, 2015. CNNIndonesia is one of the TV Media in Indonesia that has been broadcasting since August 17, 2015. CNNIndonesia is a francised American TV stasion. Like the other TV Media, CNNIndonesia has a website that broadcasts online, CNNIndonesia.com. The objection of this research is to determine how CNNIndonesia.com developed the Indonesian simultaneous local election newsby using framing analysis of Zhongdang Pan and Gerald M. Kosicki which has 4 (four) structures: syntactic, script, thematic, and rhetoric. The result of this research indicates that CNNIndonesia.com did not demonstrate the completeness of the news, relied only from one source of information, less of support to the Indonesian Simultaneous Local Elections, and didn't support to any of candidates or the Political Party of the candidates.
\end{abstract}

Keywords: News, Online Media, Framing Analysis of Zhongdang Pan and Gerald M. Kosicki.

\begin{abstract}
Abstrak
Pilkada Serentak akan diselenggarakan pada 9 Desember 2015. CNN Indonesia adalah salah satu media yang baru saja mengudara sejak 17 Agustus 2015 lalu. CNN Indonesia merupakan stasiun televisi waralaba dari Amerika Serikat. Seperti halnya beberapa media lain, CNN Indonesia juga memiliki situs atau media online, yaitu CNNIndonesia.com. Penelitian ini bertujuan untuk mengetahui bagaimana konstruksi pemberitaan Pilkada serentak yang terdapat pada CNNIndonesia.com dengan mempergunakan analisis framing Zhongdang Pan dan Gerald M. Kosicki yang memiliki 4 (empat) struktur, yaitu sintaksis, skrip, tematik, dan retoris.Hasil penelitian menunjukkan bahwa CNNIndonesia.com kurang memperhatikan unsur kelengkapan berita, hanya mengandalkan sumber informasi dari satu pihak, kurang mendukung pelaksanaan "Pilkada Serentak" ini, dan tidak menunjukkan dukungan kepada calon tertentu maupun Partai Politik pengusung calon.
\end{abstract}

Kata Kunci: Berita, Media Online, Analisis Framing Zhongdang Pan dan Gerald M. Kosicki. 


\section{PENDAHULUAN}

Pemilihan Kepala Daerah (selanjutnya akan disebut sebagai Pilkada) akan dilaksanakan secara serentak pada hari Rabu, 9 Desember 2015 mendatang. Lebih dari 800 peserta pasangan calon sudah resmi mendaftarkan diri ke Komisi Pemilihan Umum (KPU). Bahkan, tanggal 9 Desember 2015 sudah ditetapkan sebagai hari libur nasional demi terselenggaranya pilkada yang tertib dan aman.

Ini adalah Pilkada serentak pertama yang akan diselenggarakan di Indonesia, karena sebelum-sebelumnya penyelenggaraan Pilkada dilaksanakan secara masing-masing, di daerah masing-masing. Pilkada serentak kali ini adalah untuk pemilihan Gubernur, Bupati, dan Walikota. Pilkada sendiri tidak berlaku untuk jabatan yang masa jabatannya belum berakhir (belum 5 tahun).

Pro dan kontra seputar Pilkada serentak akan terkait dengan media yang memberitakannya. Sejak diumumkannya rencana pelaksanaan Pilkada serentak awal 2015 lalu, sudah banyak media yang memberitakan hal tersebut, baik media cetak, elektronik, maupun media baru (online).

CNN Indonesia adalah stasiun televisi franchise atau waralaba yang pusatnya berada di Amerika Serikat. Apabila sebelumnya Indonesia dalam berbisnis waralaba dengan pihak asing seputar gerai seperti KFC, McDonald's, dan Starbucks, atau program televisi seperti Indonesian Idol, X-Factor Indonesia, dan Masterchef Indonesia, maka bisa dikatakan bahwa ini adalah bisnis waralaba berbentuk stasiun televisi pertama yang ada di Indonesia.

CNN Indonesia merupakan kependekan dari Cable News Network Indonesia, adalah milik Trans Media dan Turner Broadcasting System. Pertama kali diluncurkan pada tanggal 17 Agustus2015 sekitar pada pukul 09.00 WIB oleh Budiono Darsono. CNN Indonesia menjadi kanal CNN pertama di Asia. Untuk sementara, CNN Indonesia hanya tersedia di televisi berlangganan TransVision. (https://id.wikipedia.org/wiki/CNN_Indonesia\#cite_note-1, diakses pada 3 Desember 2015, pukul 10.42).

Media saat ini umumnya memiliki media online, begitu juga dengan CNN Indonesia, yaitu www.cnnindonesia.com dan melalui saluran video youtube dengan nama www.youtube.com/user/CNNindonesiayang merupakan dokumentasi tayangan stasiun televisi CNN Indonesia sendiri.Media online diperuntukan bagi mereka yang karena kesibukannya tidak memiliki banyak waktu untuk menonton televisi namun masih ingin mengikuti berita-berita terkini baik dalam dan luar negeri. Media online sendiri memiliki keuntungan yaitu beritanya bisa "diputar ulang" dan bahkan didokumetasikan, tidak seperti media elektronik.

CNN Indonesia merupakan media baru di Indonesia, walaupun CNN sendiri bukan. Bagaimana CNN Indonesia mengemas berita menjadi ciri khas tersendiri dan umumnya menyimpan pesan-pesan khusus yang ingin disampaikan kepada komunikannya.

Media massa memang harusnya bersifat netral dalam memberitakan sesuatu, tidak boleh memihak siapapun apalagi untuk kepentingan politik, terutama apabila dihubungkan dengan "pesta rakyat" seperti Pilkada 2015 ini. Demikian juga dengan CNN Indonesia. 
Harus bersikap netral dalam memberitakan, tidak boleh memihak pasangan calon dari pihak tertentu ataupun partai politik pengusung pasangan calon.

Sementara, seperti yang sudah diuraikan di atas, media online memiliki beberapa keuntungan diantaranya beritanya bisa "diputar-ulang" dan didokumentasikan. Hal ini memberikan kemudahan bagi suatu penelitian seputar isi pemberitaan. Sedangkan dalam pemberitaan secara tulisan lebih bisa terlihat bagaimana peran wartawan dalam menyusun suatu berita apabila dibandingkan dengan pemberitaan secara audio-visual.

Pilkada serentak pertama, CNN Indonesia yang merupakan media baru, dan "cnnindonesia.com" sebagai media online yang akan memberikan kemudahan dalam memperoleh data yang terdiri dari tulisan dan gambar, menarik perhatian peneliti untuk menjadikannya sebagai bahan penelitian. Mempergunakan analisis framing, yang artinya bagaimana media membingkai suatu berita dengan maksud untuk mengetahui bagaimana "cnnindonesia.com" mengemas berita seputar Pilkada serentak 2015 ini. Sedangkan framing yang akan dipakai adalah framing model Zhongdang Pan dan Gerald M. Kosicki, yang terdiri atas 4 (empat) struktur, yaitu sintaksis, skrip, tematik, dan retoris.

Adapun berita yang diambil adalah 1 (satu) berita sebelum pelaksanaan, 1 (satu) berita pada saat pelaksanaan, 1 (satu) berita setelah pelaksanaan, 1 (satu) berita hasil resmi Pilkada serentak yang telah disahkan oleh KPUD, dan 1 (satu) berita pelantikan Kepala Daerah yang baru. Total sebanyak 5 (lima) buah.

Berdasarkan latar belakang permasalahan di atas, maka rumusan masalah dalam penelitian ini adalah "Bagaimana konstruksi pemberitaan "Pilkada Serentak 9 Desember 2015" pada media online "cnnindonesia.com" dengan mempergunakan analisis framing Zhongdang Pan dan Gerald M. Kosicki?

\section{KERANGKA PEMIKIRAN}

\section{Analisis Framing}

Analisis farming Zhongdang Pan dan Gerald M. Kosicki termasuk ke dalam varian dari analisis wacana secara umum.

Analisis framing secara sederhana dapat digambarkan sebagai analisis untuk mengetahui bagaimana realitas (peristiwa, aktor, kelompok, atau apa saja) dibingkai oleh media. Pembingkaian tersebut terntu saja melalui proses konstruksi. Di sini realitas sosial dimaknai dan dikonstruksi dengan makna tertentu. Peristiwa dipahami dengan bentukan tertentu. Hasilnya, pemberitaan media pada sisi tertentu atau wawancara dengan orangorang tertentu. Semua elemen tersebut tidak hanya bagian dari teknis jurnalistik, tetapi menandakan bagaimana peristiwa dimaknai dan ditampilkan. Misalnya, langkah Memorandum yang diaujkan DPR kepada Presiden Gus Dur bisa saja dimaknai dan dipahami sebagai upaya DPR melakukan kontrol dan pengawasan kepada pemerintah. Bisa juga Memorandum DPR itu dimaknai oleh media sebagai upaya menjatuhkan Presiden dan dilakukan oleh orang-orang yang tidak suka dengan Gus Dur. Bagaimana media memahami dan memaknai realitas, dan dengan cara apa realitas itu ditandakan, hal inilah yang menjadi pusat perhatian dari analisis framing. Praktisnya, ia digunakan untuk melihat bagaimana aspek tertentu ditonjolkan atau ditekankan oleh media. Penonjolan atau 
penekanan aspek tertentu dari realitas tersebut haruslah dicermati lebih jauh. Karena penonjolan atau penekanan aspek tertentu dari realitas tersebut akan membuat (hanya) bagian tertentu saja yang lebih bermakna, lebih mudah diingat, dan lebih mengena dalam pikiran khalayak. Ia juga diikuti oleh akibat yang lain, kita kemudian jadi melupakan aspek lain yang bisa jadi jauh lebih berarti dan berguna dalam menggambarkan realitas (Eriyanto, 2007: 3-4).

Dalam ranah studi komunikasi, analisis framing mewakili tradisi yang mengedepankan pendekatan atau perspektif multidisipliner untuk menganalisis fenomena atau aktivitas komunikasi. Konsep tentang framing atau frame sendiri bukan murni konsep ilmu komunikasi, akan tetapi dipinjam dari ilmu kognitif (psikologis). Dalam praktiknya, analisis framing juga membuka peluang bagi implementasi konsep-konsep sosiologis, politik, dan kultural untuk menganalisis fenomena komunikasi, sehingga suatu fenomena dapat diapresiasi dan dianalisis berdasarkan konteks sosiologis, politis, atau kultural yang melingkupinya (Sudibyo, 1999b: 176, dalam Sobur, 2004: 162).

Analisis framing dipakai untuk membedah cara-cara atau ideologi media saat mengkonstruksi fakta. Analisis ini mencermati strategi seleksi, penonjolan, dan pentautan fakta ke dalam berita agar lebih bermakna, lebih menarik, lebih berarti atau lebih diingat, untuk menggiring interpretasi khalayak sesuai perspektifnya. Dengan kata lain, framing adalah pendekatan untuk mengetahui bagaimana perspektif atau cara menulis berita. Cara pandang atau perspektif itu pada akhirnya menentukan fakta apa yang diambil, bagian mana yang ditonjolkan dan dihilangkan, serta hendak dibawa ke mana berita tersebut (Nugroho, Eriyanto, Surdiasis, 1999:21, dalam Sobur, 2004: 162). Karenanya, berita menjadi manipulatif dan bertujuan mendominasi keberadaan subjek sebagai sesuatu yang legitimate, objektif, alamiah, wajar, atau tak terelakakan (Imawan, 2000: 66, dalam Sobur, 2004: 162).

Dalam analisis framing, yang kita lihat adalah bagaimana cara media memaknai, memahami, dan membingkai kasus/peristiwa yang diberitakan. Metode semacam ini tentu saja berusaha mengerti (verstehen), dan menafsirkan makna dari suatu teks dengan jalan menguraikan bagaimana media membingkai isu. Peristiwa yang sama bisa jadi dibingkai secara berbeda oleh media (Eriyanto, 2007: 9-10).

\section{Analisis Framing Zhongdang Pan dan Gerald M. Kosicki}

Bagi Pan dan Kosicki, analisis framing dapat menjadi salah satu alternatif dalam menganalisis teks media di samping analisis isi kuantitatif. Analisis framing dilihat sebagai wacana publik tentang suatu isu atau kebijakan dikonstruksikan dan dinegosiasikan. Model yang diperkenalkan oleh Pan dan Kosicki ini tidak dapat dilepaskan dari konteks sosial politik Amerika (dalam Eriyanto, 2007: 251-252).

Dengan cara apa wartawan atau media menonjolkan pemaknaan atau penafsiran mereka atas suatu peristiwa? Wartawan memakai secara strategis kata, kalimat, lead, hubungan antarkalimat, foto, grafik, dan perangkat lain untuk membantu dirinya mengungkapkan pemaknaan mereka sehingga dapat dipahami oleh pembaca. Perangkat 
wacana itu dapat juga menjadi alat bagi peneliti untuk memahami bagaimana media mengemas peristiwa (Eriyanto, 2007: 254).

Framing Zhongdang Pan dan Gerald M. Kosicki membagi analisis ke dalam empat struktur, yaitu sintaksis, skrip, tematik, dan retoris. Pertama, struktur sintaksis. Sintaksis berhubungan dengan bagaimana wartawan menyusun peristiwa. Kedua, struktur skrip. Skrip berhubungan dengan bagaimana wartawan mengisahkan atau menceritakan peristiwa ke dalam bentuk berita. Ketiga, struktur tematik. Tematik berhubungan dengan bagaimana wartawan mengungkapkan pandangannya atas peristiwa ke dalam proposisi, kalimat, atau hubungan antarkalimat yang membentuk teks secara keseluruhan. Keempat, struktur retoris. Retoris berhubungan dengan bagaimana wartawan menekankan arti tertentu ke dalam berita. Keempat struktur tersebut merupakan suatu rangkaian yang dapat menunjukkan framing dari suatu media. Pendekatan itu dapat digambarkan ke dalam bentuk skema sbb. (Eriyanto, 2007: 255-256):

Tabel 1

Framing Zhongdang Pan dan Gerald M. Kosicki

\begin{tabular}{|c|c|c|}
\hline Struktur & Perangkat Framing & Unit yang Diamati \\
\hline $\begin{array}{c}\text { SINTAKSIS } \\
\text { Cara wartawan } \\
\text { menyusun fakta }\end{array}$ & 1. Skema Berita & $\begin{array}{l}\text { Headline, lead, latar informasi, kutipan sumber, } \\
\text { pernyataan, penutup }\end{array}$ \\
\hline $\begin{array}{c}\text { SKRIP } \\
\text { Cara wartawan } \\
\text { mengisahkan fakta }\end{array}$ & $\begin{array}{l}\text { 2. Kelengkapan } \\
\text { Berita }\end{array}$ & $5 \mathrm{~W}+1 \mathrm{H}$ \\
\hline $\begin{array}{c}\text { TEMATIK } \\
\text { Cara wartawan } \\
\text { menulis fakta }\end{array}$ & $\begin{array}{l}\text { 3. Detail } \\
\text { 4. Koherensi } \\
\text { 5. Bentuk Kalimat } \\
\text { 6. Kata Ganti }\end{array}$ & $\begin{array}{llll}\text { Paragraph, proposisi, } & \text { kalimat, } & \text { hubungan } \\
\text { antarkalimat }\end{array}$ \\
\hline $\begin{array}{c}\text { RETORIS } \\
\text { Cara wartawan } \\
\text { menekankan fakta }\end{array}$ & $\begin{array}{l}\text { 7. Leksikon } \\
\text { 8. Grafis } \\
\text { 9. Metafora }\end{array}$ & Kata, idiom, gambar/foto, grafik. \\
\hline
\end{tabular}

\section{METODE PENELITIAN}

Paradigma penelitian yang dipergunakan adalah paradigma konstruktivis, di mana bahasa tidak lagi hanya dilihat sebagai alat untuk memahami realitas objektif belaka dan yang dipisahkan dari subjek sebagai penyampai pernyataan. Bahasa dipahami dalam paradigma ini diatur dan dihidupkan oleh pernyataan-pernyataan yang memiliki tujuan. Setiap pernyataan pada dasarnya adalah tindakan penciptaan makna, yakni tindakan pembentukan diri serta pengungkapan jati diri dari sang pembicara. Wacana adalah suatu upaya pengungkapan maksud tersembunyi dari sang subjek yang mengemukakan suatu 
pernyataan. Pengungkapan itu dilakukan di antaranya dengan menempatkan diri pada posisi sang pembicara dengan penafsiran mengikuti struktur makna dari sang pembicara (Eriyanto, 2001: 4-7).

Pendekatan yang dianggap sesuai dengan penelitian ini adalah pendekatan kualitatif. Pendekatan kualitatif dianggap sesuai untuk memberikan gambaran yang menyeluruh (holistic) mengenai realitas yang dikonstruksikan ke dalam suatu wacana media film. Realitas yang dikostruksikan ini diasumsikan bersifat ganda, rumit, semu, dinamis (mudah berubah), dan kebenarannya bersifat relatif (Mulyana, 2003: 147).

Dalam penelitian ini akan diteliti mengenai bagaimana konstruksi pemberitaan Pilkada 9 Desember 2015 pada media online www.cnnindonesia.com. Metode penelitian yang digunakan untuk meneliti dan menganalisis data penelitian ini adalah analisis framing Zhongdang Pan dan Gerald M. Kosicki.

Unit analisis dalam penelitian ini adalah konstruksi pemberitaan Pilkada Serentak 9 Desember 2015 dalam www.cnnindonesia.com yang kemudian akan dianalisis mempergunakan analisis framing Zhongdang Pan dan Gerald M. Kosicki. Adapun berita yang diambil adalah 1 (satu) berita sebelum pelaksanaan, 1 (satu) berita pada saat pelaksanaan, 1 (satu) berita setelah pelaksanaan, 1 (satu) berita hasil resmi Pilkada serentak yang telah disahkan oleh KPU, dan 1 (satu) berita rencana peresmian pengangkatan Kepala Daerah yang baru. Total sebanyak 5 (lima) buah.

Menurut Huberman dan Miles, seperti yang dikutip oleh Burhan Bungin, terdapat beberapa tahap dalam analisis data yang umum dilakukan dalam penelitian kualitatif, yaitu (Bungin, 2003: 69):

1. Kategorisasi dan reduksi data. Di sini, peneliti mengumpulkan informasi-informasi yang penting yang terkait dengan masalah penelitian, dan selanjutnya mengelompokkan data tersebut sesuai dengan topik masalahnya.

2. Sajian data. Data yang terkumpul dan telah dikelompokkan itu kemudian disusun sistematis sehingga peneliti dapat melihat dan menelah komponen-komponen penting dari sajian data.

3. Penarikan kesimpulan. Pada tahap ini, peneliti melakukan interpretasi data sesuai dengan konteks permasalahan dan tujuan penelitian. Dari interpretasi yang dilakukan akan diperoleh kesimpulan dalam menjawab masalah penelitian.

HASIL PENELITIAN DAN PEMBAHASAN

a. Jelang Pilkada Isu Politik Uang Merebak, 8 Desember 2015, 06:54 WIB

Tabel 2

Analisis Framing Berita “Jelang Pilkada Isu Politik Uang Merebak"

\begin{tabular}{|l|l|ll|}
\hline Struktur & Unit yang Diamati & Hasil Pengamatan & \\
\hline Sintaksis & Judul & Jelang Pilkada Isu Politik Uang Merebak & \\
\hline & Lead & $\begin{array}{l}\text { Kemungkinan terjadinya kecurangan dalam } \\
\text { Pilkada akibat politik uang. }\end{array}$ \\
\hline
\end{tabular}




\begin{tabular}{|c|c|c|}
\hline & Latar informasi & $\begin{array}{l}\text { Sejumlah pasangan calon yang menjanjikan } \\
\text { memberikan imbalan sejumlah uang dan gratis } \\
\text { biaya transportasi. }\end{array}$ \\
\hline & Kutipan sumber & $\begin{array}{l}\text { Pernyataan warga } \quad \text { yang } \\
\text { dijanjikan/ditawarkan uang oleh kandidat atau tim } \\
\text { suksesnya. }\end{array}$ \\
\hline & Pernyataan & $\begin{array}{l}\text { - Calon bupati dan wakil bupati menawarkan } \\
\text { uang kepada para pemilih. } \\
\text { - Kandidat memberikan uang panjar sejak awal } \\
\text { masa kampanye. } \\
\text { - Calon bupati dan wakil bupati menggratiskan } \\
\text { penumpang kapal tujuan Kendari-Wangiwangi } \\
\text { apabila memilih pemilik kapal, apabila tidak } \\
\text { maka tidak diijinkan menaiki kapal tersebut. }\end{array}$ \\
\hline & Penutup & $\begin{array}{l}\text { Harapan dari semua pihak agar Pilkada serentak } \\
\text { ini berjalan dengan lancar. }\end{array}$ \\
\hline Skrip & What & Politik uang dalam Pilkada. \\
\hline & Where & Sulawesi Tenggara. \\
\hline & When & Sejak awal masa kampanye. \\
\hline & Who & Kandidat atau pasangan calon. \\
\hline & Why & Tidak ada dalam berita. \\
\hline & How & $\begin{array}{l}\text { Para warga ditawari sejumlah uang atau imbalan } \\
\text { jasa apabila memilih calon ybs. }\end{array}$ \\
\hline Tematik & $\begin{array}{l}\text { Paragraph, proposisi, } \\
\text { kalimat, hubungan antar } \\
\text { kalimat }\end{array}$ & $\begin{array}{l}\text { Keseluruhan berita menunjukkan adanya praktik } \\
\text { kecurangan dalam Pilkada yang terjadi di Sulawesi } \\
\text { Selatan. }\end{array}$ \\
\hline Retoris & $\begin{array}{l}\text { Kata, idiom, gambar, } \\
\text { grafik. }\end{array}$ & $\begin{array}{l}\text { - "Isu" menunjukkan bahwa peristiwa ini masih } \\
\text { belum pasti, masih perlu dibuktikan } \\
\text { kebenarannya. } \\
\text { - "Politik uang" di sini mempunyai arti adanya } \\
\text { ketidak jujuran dalam pelaksanaan Pilkada, } \\
\text { artinya sejumlah kandidat atau pasangan calon } \\
\text { menyuap warga dengan sejumlah uang untuk } \\
\text { memilihnya agar menang di Pilkada. } \\
\text { - Gambar yang dimunculkan adalah pekerja yang } \\
\text { menyortir kertas suara di Sulawesi Tenggara. } \\
\text { Hal ini menunjukkan bahwa panitia siap } \\
\text { melaksanakan Pilkada khususnya di daerah } \\
\text { Sulawesi. Gambarnya sendiri selective focus } \\
\text { pada kertas suara, menunjukkan bahwa yang } \\
\text { terpenting dari pelaksanaan Pilkada ini adalah } \\
\text { kertas suara itu sendiri. }\end{array}$ \\
\hline
\end{tabular}




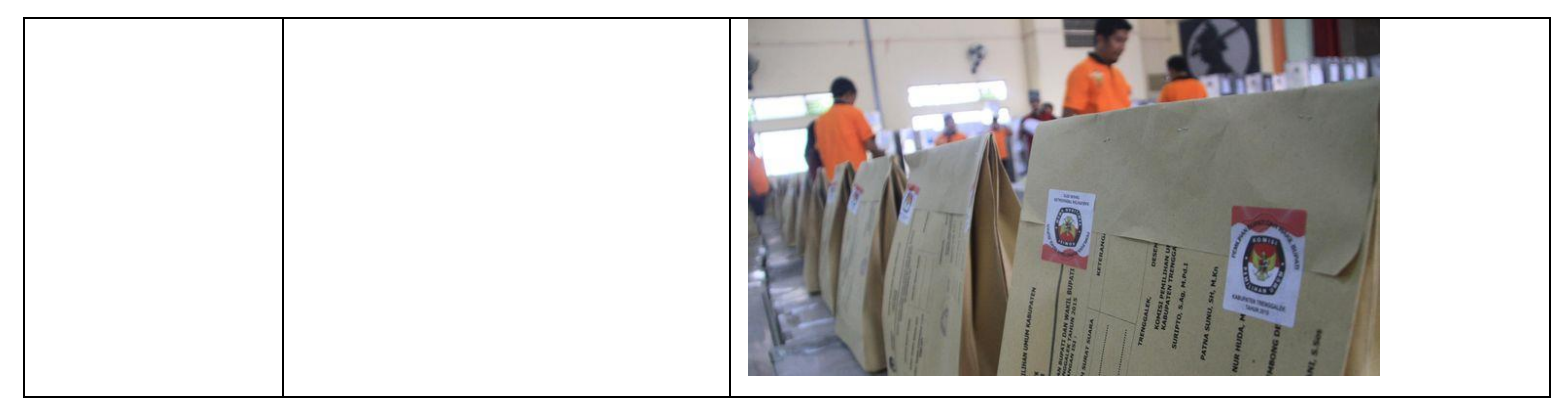

Analisis:

1. Sintaksis.

Berita ini menggambarkan kemungkinan terjadinya kecurangan dalam Pilkada akibat politik uang. Sejumlah warga yang dimintai keterangan menjadi dasar munculnya pemberitaan ini. Warga yang secara langsung dihubungi oleh tim sukses kandidat menyatakan bahwa mereka dihubungi dengan diiming-imingi sejumlah uang asalkan mau memilih pasangan calon tertentu. Tidak ada keterangan atau pernyataan dari tim sukses ataupun pasangan calon mengenai hal ini, terlebih dalam berita juga disebutkan secara jelas nama pasangan calon yang - menurut warga - telah melakukan politik uang. Berita di sini hanya mengandalkan pendapat dari satu pihak saja, yakni warga yang diduga telah diiming-imingi sejumlah uang tersebut.

2. Skrip.

Tidak adanya unsur why kemungkinan karena sudah bisa dipahami bahwa tindakan politik uang dari para calon dikarenakan mereka ingin memenangkan Pilkada. Walaupun tindakan yang dilakukan adalah oleh kandidat atau pasangan calon, namun keterangan hanya berasal dari warga setempat saja. Padahal kecurigaan ini sudah muncul sejak awal masa kampanye, namun tidak ada tindakan lebih lanjut atas pihak pasangan calon ataupun tim suksesnya yang telah melakukan tindakan curang tersebut.

3. Tematik.

Secara keseluruhan, berita ini mengusung tema adanya praktik kecurangan dalam Pilkada yang terjadi di Sulawesi Selatan. Namun, tidak ada bukti-bukti yang diperlihatkan untuk menguatkan informasi tersebut juga tidak ada keterangan dari pasangan calon yang disebutkan namanya ataupun tim suksesnya. Maka dari itu dalam berita ini tidak ada check and recheck alias informasi yang ditulis hanya dari satu pihak saja, yaitu warga setempat.

4. Retoris.

Secara retoris berita ini seolah membangun citra pelaksanaan Pilkada yang tidak jujur dan adil, karena adanya isu kecurangan berupa penyuapan kepada warga dari kandidat atau pasangan calon yang terjadi di Sulawesi Tenggara. Apabila didukung dengan pemilihan gambar yang fokus pada kertas suara, menunjukkan bahwa kerja keras panitia dalam Pilkada akan tercoreng apabila Pilkada berjalan tidak jujur dan 
adil. Kertas suara yang menjadi bagian terpenting dalam pelaksanaan Pilkada ini akan terkesan percuma apabila pemilih tidak mempergunakan hak suaranya untuk memilih secara bebas dan rahasia. Padahal kata "isu" merupakan kata yang mengandung makna bahwa informasi tersebut masih membutuhkan bukti agar benar-benar dapat diyakini kebenarannya.

\section{b. Amankan Pilkada, Polisi Poso Diminta Waspadai Ancaman Teror, 9 Desember 2015, 11:20 WIB.}

Tabel 3

Analisis Framing Berita “Amankan Pilkada, Polisi Poso Diminta Waspadai Ancaman Teror"

\begin{tabular}{|c|c|c|}
\hline Struktur & Unit yang Diamati & Hasil Pengamatan \\
\hline \multirow[t]{6}{*}{ Sintaksis } & Judul & $\begin{array}{l}\text { Amankan Pilkada, Polisi Poso Diminta Waspadai } \\
\text { Ancaman Teror }\end{array}$ \\
\hline & Lead & $\begin{array}{l}\text { Memperketat pengamanan agar terhindar dari } \\
\text { teroris kelompok Santoso. }\end{array}$ \\
\hline & Latar informasi & $\begin{array}{l}\text { Kelompok teroris Santoso berbasis di Poso, dan } \\
\text { belum tertangkap. }\end{array}$ \\
\hline & Kutipan sumber & Kapolri Jendral Badrodin Haiti. \\
\hline & Pernyataan & $\begin{array}{l}\text { - Perintah Badrodin untuk tetap waspada sampai } \\
\text { perhitungan suara selesai, jangan sampai lemah } \\
\text { kekuatan, harus kompak, dan jangan ada yang } \\
\text { bergerak sendirian. } \\
\text { - Pengejaran kelompok Santoso harus tetap } \\
\text { berjalan bersamaan dengan pengamanan } \\
\text { Pilkada. }\end{array}$ \\
\hline & Penutup & $\begin{array}{l}\text { Informasi pengamanan Pilkada oleh sejumlah } \\
\text { aparat kepolisian dan TNI. }\end{array}$ \\
\hline \multirow[t]{6}{*}{ Skrip } & What & $\begin{array}{l}\text { Perintah perketat pengamanan jalannya Pilkada } \\
\text { dari ancaman teror kelompok Santoso. }\end{array}$ \\
\hline & Where & Poso, Sulawesi Tengah \\
\hline & When & 9 Desember 2015 \\
\hline & Who & Kapolri Jendral Badrodin Haiti \\
\hline & Why & $\begin{array}{l}\text { Kelompok Santoso berbasis di Poso, dan belum } \\
\text { tertangkap. }\end{array}$ \\
\hline & How & $\begin{array}{l}\text { Kekuatan personel jangan sampai lemah, kompak, } \\
\text { dan jangan ada yang bergerak sendirian. }\end{array}$ \\
\hline Tematik & $\begin{array}{l}\text { Paragraph, proposisi, } \\
\text { kalimat, hubungan antar } \\
\text { kalimat }\end{array}$ & $\begin{array}{l}\text { Dari awal sampai akhir menuliskan tentang } \\
\text { pengamanan jalannya Pilkada, khususnya oleh } \\
\text { Polri. }\end{array}$ \\
\hline Retoris & $\begin{array}{l}\text { Kata, idiom, gambar, } \\
\text { grafik. }\end{array}$ & $\begin{array}{l}\text { - Kata-kata seperti "waspada", "keamanan" } \\
\text { mengindikasikan bahwa kondisi pelaksanaan } \\
\text { Pilkada khususnya di Poso tidak aman, rentan }\end{array}$ \\
\hline
\end{tabular}




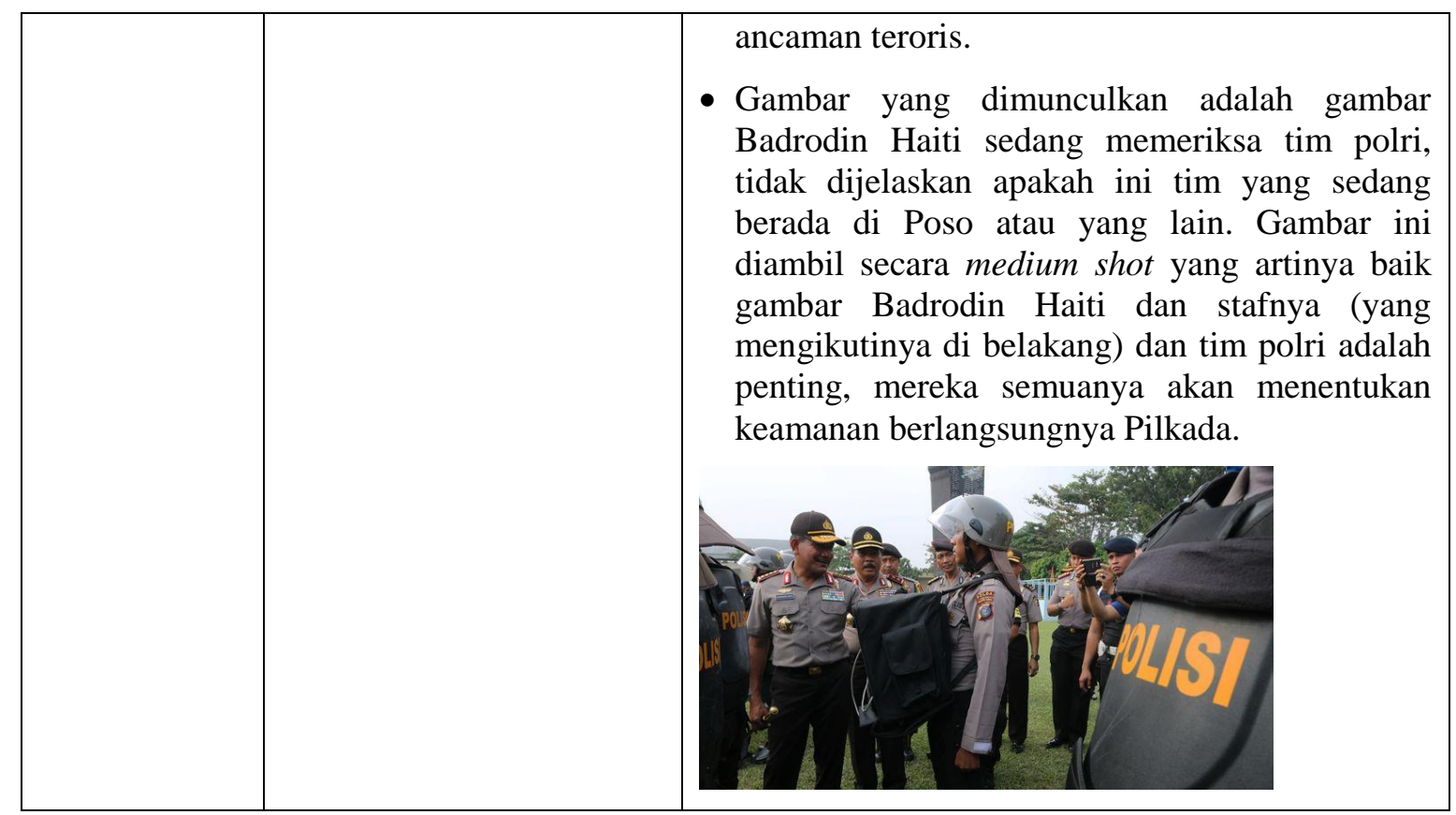

Analisis:

1. Sintaksis.

Terhadap kekhawatiran dalam hal keamanan pada saat berlangsungnya Pilkada, khususnya di Poso. Hal ini disebabkan kelompok teroris Santoso yang berbasis di Poso belum tertangkap dan dikhawatirkan bisa mengancam jalannya Pilkada. Tidak hanya di Poso, pengamanan juga dilakukan di tempat-tempat lain di mana melibatkan satuan TNI dan Polri. Teroris umumnya mengincar kerumunan orang banyak untuk kemudian melaksanakan aksinya. Karena itu dapat dimaklumi apabila keamanan jalannya Pilkada menjadi hal yang penting untuk dapat menciptakan situasi dan kondisi Pilkada yang aman dan tentram, khususnya bagi warga. Berita di sini mengandalkan dari satu sumber saja, yaitu Kapolri Jendral Badrodin Haiti, yang tampaknya sudah dianggap cukup untuk menyatakan status keamanan pelaksanaan Pilkada di Poso yang harus lebih diperketat.

2. Skrip.

Penulisan berita ini lengkap karena semua unsur $5 \mathrm{~W}+1 \mathrm{H}$ terdapat di dalamnya. Dari mulai apa permasalahan, siapa yang memberikan perintah, sampai dengan alasan dan bagaimana mengatasi permasalahan tersebut.

3. Tematik.

Secara keseluruhan, berita ini mengusung tema adanya kemungkinan ancaman teroris yang bisa mengganggu jalannya pelaksanaan Pilkada, khususnya di Poso. Untuk mengantisipasinya, pihak Polri sudah mengambil langkah untuk memperketat pengamanan. Keterangan yang diambil hanya dari satu pihak, yaitu Polri. Tidak ada keterangan dari panitia ataupun warga sekitar untuk menguatkan apa yang dikhawatirkan oleh Polri mengenai keamanan tersebut.

4. Retoris. 
Secara retoris, berita ini memberikan citra jalannya Pilkada si Poso yang tidak aman karena rentan serangan teroris. Dalam gambar tidak dijelaskan Badrodin Haiti sedang memeriksa tim polri yang mana. Tim polri yang sedang diperiksa juga tidak jelas akan ditugaskan di mana. Gambar tidak menunjukkan situasi di Poso itu sendiri, gambar fokus pada apa yang dilakukan Badrodin Haiti.

\section{c. Pilkada Tiga Daerah Dengan Calon Tunggal Dinilai Lancar, 10 Desember 2015, 13:35 WIB}

Tabel 4

Analisis Framing Berita "Pilkada Tiga Daerah Dengan Calon Tunggal Dinilai Lancar"

\begin{tabular}{|c|c|c|}
\hline Struktur & Unit yang Diamati & Hasil Pengamatan \\
\hline \multirow[t]{6}{*}{ Sintaksis } & Judul & $\begin{array}{l}\text { Pilkada Tiga Daerah Dengan Calon Tunggal } \\
\text { Dinilai Lancar }\end{array}$ \\
\hline & Lead & $\begin{array}{l}\text { Jalannya Pilkada dengan calon tunggal di } \\
\text { Kabupaten Timor Tengah Utara, Blitar, dan } \\
\text { Tasikmalaya yang dinilai lancar. }\end{array}$ \\
\hline & Latar informasi & $\begin{array}{l}\text { Belum adanya laporan dari KPUD terkait adanya } \\
\text { masalah dengan satu calon tunggal. }\end{array}$ \\
\hline & Kutipan sumber & Komisioner KPU Hadar Nafis Gumay \\
\hline & Pernyataan & $\begin{array}{l}\text { - Sampai pernyataan ini disampaikan, } \\
\text { pelaksanaan Pilkada dengan calon tunggal } \\
\text { berjalan lancar, karena belum adanya laporan } \\
\text { timbul masalah dari daerah-daerah ybs. } \\
\text { - Mengapresiasi angka presentase keikutsertaan } \\
\text { Pilkada dengan calon tunggal. }\end{array}$ \\
\hline & Penutup & Informasi wilayah/daerah yang mengikuti Pilkada. \\
\hline \multirow[t]{6}{*}{ Skrip } & What & $\begin{array}{l}\text { Pelaksanaan Pilkada yang mengusung calon } \\
\text { tunggal di } 3 \text { (tiga) wilayah dinilai lancar. }\end{array}$ \\
\hline & Where & $\begin{array}{l}\text { Kabupaten Timor Tengah Utara (NTT), Blitar } \\
\text { (Jawa Timur), dan Tasikmalaya (Jawa Barat). }\end{array}$ \\
\hline & When & 9 Desember 2015 \\
\hline & Who & Komisioner KPU Hadar Nafis Gumay \\
\hline & Why & $\begin{array}{l}\text { KPU Pusat belum menerima laporan adanya } \\
\text { masalah dari KPUD terkait. }\end{array}$ \\
\hline & How & Tidak ada dalam berita. \\
\hline Tematik & $\begin{array}{l}\text { Paragraph, proposisi, } \\
\text { kalimat, hubungan antar } \\
\text { kalimat }\end{array}$ & $\begin{array}{l}\text { Menuliskan berita mengenai kelancaran } \\
\text { pelaksanaan Pilkada dengan calon tunggal di } 3 \\
\text { (tiga) wilayah, yaitu Kabupaten Timor Tengah } \\
\text { Utara (NTT), Blitar (Jawa Timur), dan } \\
\text { Tasikmalaya (Jawa Barat). }\end{array}$ \\
\hline Retoris & $\begin{array}{l}\text { Kata, idiom, gambar, } \\
\text { grafik. }\end{array}$ & $\begin{array}{l}\text { - Kata-kata "lancar" dan "calon tunggal" } \\
\text { menunjukkan awalnya ada kekhawatiran apabila }\end{array}$ \\
\hline
\end{tabular}




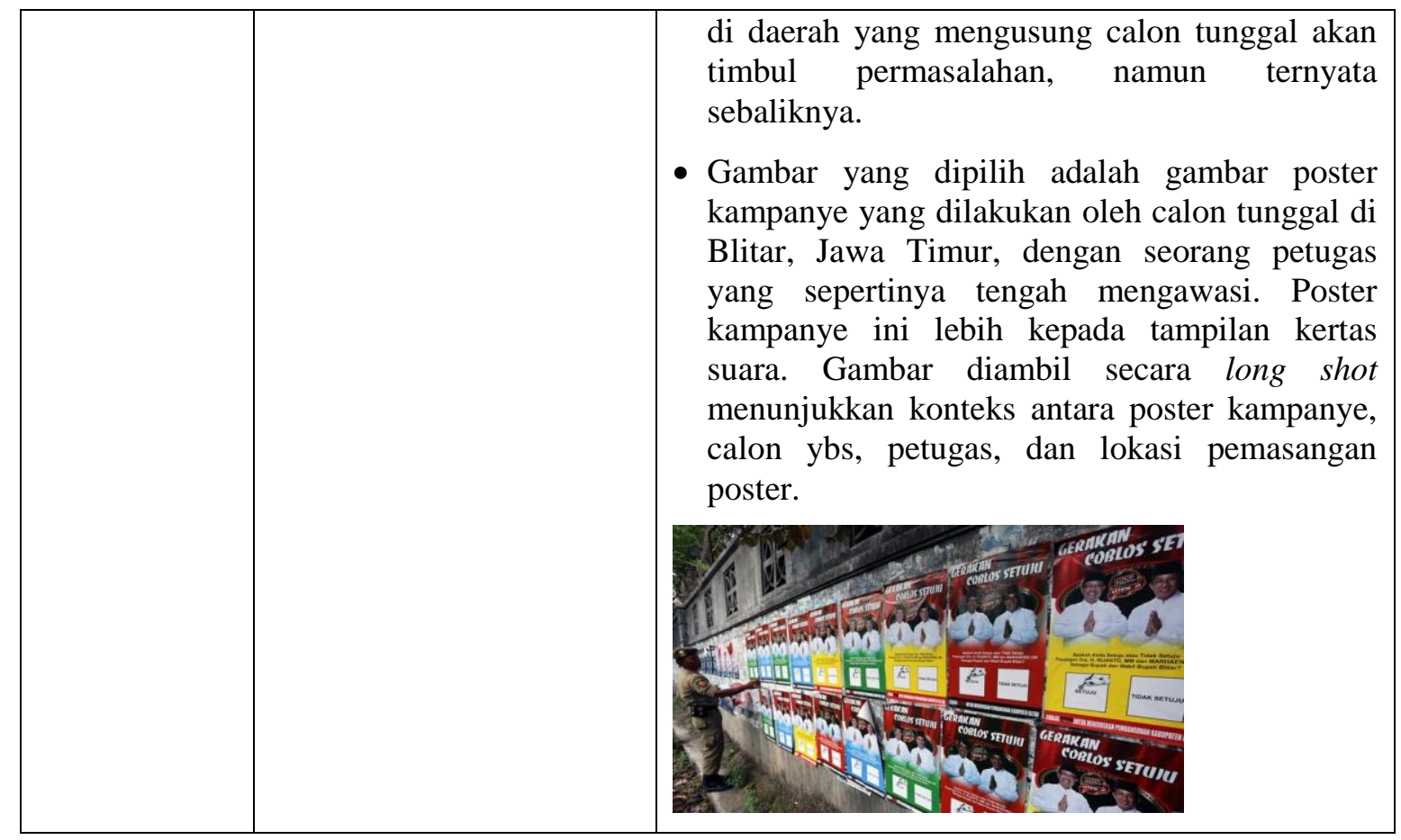

Analisis:

1. Sintaksis.

Dari struktur sintaksis terlihat bahwa pelaksanaan Pilkada di 3 (tiga) daerah yang mengusung calon tunggal relatif berjalan dengan aman karena belum adanya laporan dari KPUD setempat mengenai permasalahan yang timbul di daerah-daerah tersebut. Lancar di sini diartikan bahwa warga setempat setidaknya banyak yang ikut berpatisipasi dengan mengikuti Pilkada tersebut, tidak banyak yang bersikap golput karena mereka sebetulnya bisa memilih antara "ya" atau "tidak" alias "setuju" atau "tidak setuju" atas calon tunggal yang diusung. Di sini tidak disebutkan calon-calon tunggal tersebut apakah diusung partai politik tertentu atau calon independen.

Dengan hanya mengandalkan pendapat dari satu pihak, yaitu pihak KPU Pusat, menunjukkan bahwa masyarakat tidak perlu khawatir dengan adanya Pemilihan, khususnya Kepala Daerah, dengan calon tunggal. Tidak ada keterangan langsung dari KPUD setempat seolah-olah mengindikasikan apa yang sudah disampaikan oleh KPU Pusat adalah cukup, walaupun hanya dengan mengandalkan "belum adanya laporan dari KPUD yang bersangkutan".

2. Skrip.

Berita ini tidak memenuhi unsur how, artinya tidak dijelaskan secara rinci bagaimana proses yang sesungguhnya di lapangan sehingga pemilihan calon tunggal di 3 (tiga) daerah tersebut berjalan aman.

3. Tematik.

Mengusung tema kelancaran pelaksanaan Pilkada di daerah yang mengusung calon tunggal, karena tidak ada masalah yang dilaporkan oleh KPUD setempat. Tidak ada 
informasi dari KPUD atau warga setempat mengenai jalannya Pilkada di daerah dimaksud. Keterangan hanya dari satu pihak saja, yaitu KPU Pusat.

4. Retoris.

Awalnya seperti timbul kekhawatiran apabila Pilkada calon tunggal akan timbul permasalahan. Berita ini ingin memberikan citra bahwa calon tunggal juga bisa ikut meramaikan jalannya Pilkada. Gambar yang dipilih juga menunjukkan poster kampanye sekaligus petunjuk bagaimana cara memilih calon tunggal pada saat Pilkada, karena tampilannya atau design dari poster kampanye tersebut lebih mirip kertas suara, bukan menuliskan visi dan misi ataupun slogan dukungan terhadap pasangan calon.

d. MK Tolak Nyaris Seluruh Permohonan Sengketa Pilkada, 18 Januari 2016, 16:48 WIB.

Tabel 5

Analisis Framing Berita "MK Tolak Nyaris Seluruh Permohonan Sengketa Pilkada"

\begin{tabular}{|c|c|c|}
\hline Struktur & Unit yang Diamati & Hasil Pengamatan \\
\hline \multirow[t]{6}{*}{ Sintaksis } & Judul & $\begin{array}{l}\text { MK Tolak Nyaris Seluruh Permohonan Sengketa } \\
\text { Pilkada }\end{array}$ \\
\hline & Lead & $\begin{array}{l}\text { Sidang putusan sesi kedua Mahkamah Konstitusi } \\
\text { yang menolak hampir seluruh permohonan } \\
\text { sengketa Pilkada Serentak } 9 \text { Desenber } 2015 \text {. }\end{array}$ \\
\hline & Latar informasi & $\begin{array}{l}\text { Menolak } 16 \text { (enam belas) gugatan atas dasar } \\
\text { melewati batas waktu. }\end{array}$ \\
\hline & Kutipan sumber & $\begin{array}{l}\text { Tidak ada kutipan sumber, semua berupa } \\
\text { pernyataan dari wartawan. }\end{array}$ \\
\hline & Pernyataan & $\begin{array}{l}\text { - Wartawan menuliskan MK menolak } 16 \text { (enam } \\
\text { belas) dari } 21 \text { (dua puluh satu) gugatan dengan } \\
\text { alasan melewati batas waktu. } \\
\text { - Wartawan menuliskan } 5 \text { (lima) dari } 21 \text { (dua } \\
\text { puluh satu) permohonan sengketa Pilkada } \\
\text { ditarik kembali oleh pasangan calon dan kuasa } \\
\text { hukum mereka. }\end{array}$ \\
\hline & Penutup & $\begin{array}{l}\text { Situasi seputar persidangan; pengamanan jalannya } \\
\text { sidang dan kehadiran sejumlah anggota KPU } \\
\text { dalam sidang tersebut. }\end{array}$ \\
\hline \multirow[t]{5}{*}{ Skrip } & What & $\begin{array}{l}\text { Penolakan } 16 \text { (enam belas) dari } 21 \text { (dua puluh } \\
\text { satu) gugatan sengketa hasil Pilkada pada sesi } \\
\text { kedua persidangan. }\end{array}$ \\
\hline & Where & Jakarta. \\
\hline & When & 18 Januari 2016. \\
\hline & Who & Mahkamah Konstitusi. \\
\hline & Why & $\begin{array}{l}\text { Pengajuan } 16 \text { (enam belas) gugatan tersebut telah } \\
\text { melewati batas waktu. }\end{array}$ \\
\hline
\end{tabular}




\begin{tabular}{|c|c|c|}
\hline & How & Tidak ada dalam berita. \\
\hline Tematik & $\begin{array}{l}\text { Paragraph, proposisi, } \\
\text { kalimat, hubungan antar } \\
\text { kalimat }\end{array}$ & $\begin{array}{l}\text { Berita ini menginformasikan mengenai keputusan } \\
\text { MK untuk menolak } 16 \text { (enam belas) dari (dua } \\
\text { puluh satu) gugatan sengketa hasil Pilkada sesi } \\
\text { kedua (dari empat sesi) dengan mengambil sudut } \\
\text { pandang dari wartawan, di mana penolakan } \\
\text { gugatan tersebut karena telah melewati batas } \\
\text { waktu. }\end{array}$ \\
\hline Retoris & $\begin{array}{l}\text { Kata, idiom, gambar, } \\
\text { grafik. }\end{array}$ & $\begin{array}{l}\text { - Kata-kata "tolak" atau "menolak" } \\
\text { mengindikasikan bahwa di sini MK tidak mau } \\
\text { menerima gugatan hasil sengketa, seolah-olah } \\
\text { MK mendukung KPU dan KPUD mengenai } \\
\text { hasil yang telah disahkan. } \\
\text { - Gambar di sini adalah gambar Hakim MK yaitu } \\
\text { Bpk. Arief Hidayat yang tengah menangani } \\
\text { gugatan sengketa hasil Pilkada. Gambar secara } \\
\text { medium-shot menunjukkan bahwa sebagai salah } \\
\text { satu penegak keadilan, sosok Hakim MK bisa } \\
\text { diandalkan oleh masyarakat. } \\
\text { ARIEF HIDAYAT }\end{array}$ \\
\hline
\end{tabular}

Analisis:

1. Sintaksis.

Berita ini menuliskan bahwa Mahkamah Konstitusi (MK) menolak hampir semua pengajuan gugatan sengketa hasil Pilkada pada sesi yang kedua dari empat sesi, yaitu 16 (enam belas) dari 21 (dua puluh satu) gugatan. Penolakan ini dikarenakan pengajuan gugatan yang telah melewati batas waktu. Di sini artinya ada kelalaian dari pasangan calon ataupun tim suksesnya mengenai kepekaan mereka akan tenggat waktu apabila ingin mengajukan keberatan atas hasil Pilkada.

Berita ini tidak mencantumkan kutipan sumber, baik itu panitera ataupun Hakimnya secara langsung, semua merupakan pernyataan wartawan. Maka dari itu sulit dipastikan apakah ini benar-benar berdasarkan nara sumber yang dapat dipercaya ataukah hanya apa yang bisa ditangkap wartawan ataukan hanya opini wartawan saja.

2. Skrip.

Pada struktur ini, tidak dituliskan how, padahal penting adanya bagaimana sampai terjadi pasangan calon maupun kuasa hukum melewati batas waktu pengajuan gugatan; apakah kelalaian ataukah memang ada unsur lain.

3. Tematik. 
Tema di sini adalah penolakan terhadap nyaris seluruh gugatan sengketa Pilkada 2015 pada sesi kedua sidang. Tidak diinformasikan bagaimana dengan sesi pertama, ketiga, dan keempat. Dan berita di sini juga hanya menyampaikan pernyataan dari wartawan, tidak ada pernyataan atau kutipan langsung dari nara sumber yang bisa dipercaya.

4. Retoris.

Di sini seolah menunjukkan citra bahwa MK mendukung keputusan KPU dan KPUD dalam pelaksanaan Pilkada 2015 lalu. Gambar yang diambil juga tidak dijelaskan sesi keberapa (ada total empat sesi persidangan), dan juga tidak ada kejelasan Hakim MK Arief Hidayat ini memimpin berapa sesi persidangan; hanya sebagian ataukah semuanya.

e. Bupati Ogan Ilir Pakai Sabu Sehari Sebelum Pelantikan, 15 Maret 2016, 06:29 WIB.

Tabel 6

Analisis Framing Berita "Bupati Ogan Ilir Pakai Sabu Sehari Sebelum Pelantikan"

\begin{tabular}{|c|c|c|}
\hline Struktur & Unit yang Diamati & Hasil Pengamatan \\
\hline \multirow[t]{6}{*}{ Sintaksis } & Judul & $\begin{array}{l}\text { Bupati Ogan Ilir Pakai Sabu Sehari Sebelum } \\
\text { Pelantikan }\end{array}$ \\
\hline & Lead & $\begin{array}{l}\text { Bupati terpilih dari Ogan Ilir, Sumatera Selatan, } \\
\text { Ahmad Wazir Noviadi Mawardi, mempergunakan } \\
\text { narkotik jenis sabu satu hari sebelum pelantikan. }\end{array}$ \\
\hline & Latar informasi & $\begin{array}{l}\text { Tertangkapnya Bupati terpilih dari Ogan Ilir, } \\
\text { Sumatera Selatan, Ahmad Wazir Noviadi } \\
\text { Mawardi, karena kasus narkoba. }\end{array}$ \\
\hline & Kutipan sumber & $\begin{array}{l}\text { Keterangan dari Kepala Badan Narkotika Nasional } \\
\text { Komisaris Jenderal Budi Waseso. }\end{array}$ \\
\hline & Pernyataan & $\begin{array}{l}\text { - Memberikan alasan Ahmad Wazir Noviadi } \\
\text { Mawardi menggunakan sabu sehari sebelum } \\
\text { pelantikan agar bisa tampil lebih PD alias } \\
\text { Percaya Diri. } \\
\text { - Kebiasaan mengkonsumsi narkotika jenis sabu } \\
\text { ini sudah terjadi selama } 3 \text { (tiga) bulan. } \\
\text { - Penangkapan bandar yang sekaligus merupakan } \\
\text { pemasok tersangka yang merupakan Pegawai } \\
\text { Negeri Sipil (PNS) sebuah Rumah Sakit Umum } \\
\text { Daerah (RSUD) Enarldi Bahar. }\end{array}$ \\
\hline & Penutup & $\begin{array}{l}\text { Informasi bahwa Ahmad Wazir Noviadi Mawardi } \\
\text { merupakan anak dari Bupati Ogan Ilir sebelumnya, } \\
\text { Mawardi Yahya. }\end{array}$ \\
\hline \multirow[t]{4}{*}{ Skrip } & What & $\begin{array}{l}\text { Pemakaian narkotika jenis sabu oleh Bupati Ogan } \\
\text { Ilir, Sumatera Selatan, yang terpilih melalui } \\
\text { Pilkada } 2015 \text {. }\end{array}$ \\
\hline & Where & Ogan Ilir, Sumatera Selatan. \\
\hline & When & 13 Maret 2016. \\
\hline & Who & Ahmad Wazir Noviadi Mawardi \\
\hline
\end{tabular}




\begin{tabular}{|l|l|l|}
\hline & Why & Agar lebih percaya diri. \\
\hline Tematik & How & $\begin{array}{l}\text { Memiliki pemasok yang merupakan PNS RSUD } \\
\text { Enarldi Bahar bernama Faizal Roche. }\end{array}$ \\
\hline kalimat, hubungan antar \\
kalimat
\end{tabular}

Analisa:

1. Sintaksis.

Berita ini memberikan informasi mengenai kebiasaan mengkonsumsi narkotik jenis sabu yang dilakukan oleh salah satu pemimpin kepala daerah terpilih, Bupati Ogan Ilir, Ahmad Wazir Noviadi Mawardi. Kutipan sumber yang berasal dari Kepala Badan Narkotika Nasional Komisaris Jenderal Budi Waseso, namun tidak disertai keterangan dari pihak tersangka ataupun kuasa hukumnya.

2. Skrip.

Terdapat kelengkapan unsur berita yang berarti apa yang diinformasikan dari berita ini sudah memenuhi persyaratan.

3. Tematik.

Memberikan tema mengenai kebiasaan buruk seorang kepala daerah terpilih. Bagaimana seorang kepala daerah yang juga merupakan pilihan rakyat bisa mempunyai kebiasaan buruk tersebut.

4. Retoris.

Berita ini memberikan citra yang buruk atas perilaku salah satu kepala daerah, apalagi didukung dengan gambar yang tidak mencerminkan sikap seorang kepala daerah sama sekali; ekspresi datar dengan lidah sedikit terjulur yang mengesankan sikap tak perduli atas masalah yang dihadapinya. 
Media online pada umumnya memiliki kelebihan dalam hal kecepatan memberitakan sesuatu. Namun, walaupun memiliki kelebihan tersebut hendaknya unsur kelengkapan berita $5 \mathrm{~W}+1 \mathrm{H}$ tetap harus diperhatikan. Tidak semua berita dalam penelitian ini memiliki kelengkapan unsur berita $5 \mathrm{~W}+1 \mathrm{H}$. 3 (tiga) dari 5 (lima) berita tidak memiliki kelengkapan yaitu 2 (dua) berita unsur how dan 1 (satu) berita unsur why.

Berita-berita yang ada juga hanya mengandalkan sumber dari satu pihak saja, bahkan ada satu berita yang hanya menuliskan pernyataan dari wartawan. Di sini tampak ketidak berimbangan dalam menuliskan berita, karena hanya mengandalkan sumber dari satu pihak. Bagaimana suatu berita bisa dikatakan netral apabila hanya memuat keterangan dari satu pihak saja?

"Pilkada Serentak" ini seolah tidak didukung oleh media online cnnindonesia.com, karena apa yang disampaikan banyak menunjukkan citra negatif mengenai jalannya Pilkada. Citra negatif mulai dari isu politik uang, ancaman teroris, penolakan gugatan di MK. sampai Bupati terpilih yang mempergunakan narkotik jenis sabu. Hanya pemberitaan mengenai kelancaran jalannya daerah yang memiliki calon tunggal saja yang tidak mengesankan citra negatif. Apabila tidak ingin dibilang menunjukkan citra negatif maka yang bisa disampaikan adalah media ini seolah tidak mendukung pelaksanaan "Pilkada Serentak" yang merupakan hal baru terjadi di Indonesia. Tidak jelas juga mengapa media ini seolah tidak mendukung. Kesan tidak mendukung jalannya "Pilkada Serentak" ini sekaligus menunjukkan bagaimana cnnindonesia.com mengkonstruksi relitas yang ada, dengan memilih dan memberitakan hal-hal yang seolah tidak mendukung jalannya "Pilkada Serentak" tersebut.

Pemberitaan juga tidak mengusung pasangan calon yang diusung Partai Politik tertentu. Hal ini menunjukkan bahwa media ini tidak memiliki kepentingan politis terhadap Partai Politik manapun. Media cnninconesia.com tidak menjadi salah satu media partner pasangan calon ataupun Partai Politik yang mendukung pasangan calon. Ketidak berpihakan pada Partai Politik tertentu ini didukung oleh berita mengenai kelancaran jalannya calon tunggal yang tidak dikaitkan dengan Partai Politik manapun, murni hanya memberitakan mengenai calon tunggal.

Sebagai media yang baru di Indonesia, namun staf yang ada merupakan orangorang lama yang memiliki pengalaman jurnalistik dan penyiaran. Sebut saja Desi Anwar sebagai Direktur CNN Indonesia yang telah memiliki pengalaman lebih dari 20 tahun, atau M. Yusuf Arifin sebagai Pemimpin Redaksi CNNIndonesia.com yang menjadi wartawan sejak masih duduk di bangku kuliah dan memiliki pengalaman bekerja di luar negeri. Di sini yang hendak disampaikan adalah mengapa unsur kelemgkapan berita $5 \mathrm{~W}+1 \mathrm{H}$ bisa terlewat dan mengapa tidak cover both side yang artinya tidak hanya mengandalkan satu pihak saja sebagai nara sumber?

Di sisi lain CNN Indonesia secara umum adalah franchise mass media (media massa waralaba)yang berasal dari Amerika Serikat, CNN Internasional, yang memang sudah memiliki banyak cabang di berbagai Negara. Walaupun disebutkan bahwa CNN Indonesia dan CNN Internasional adalah dua lembaga yang terpisah dan bersifat independen, namun secara umum kegiatan bisnis franchise merupakan kegiatan yang tidak 
bisa saling meniadakan satu sama lain, antara franchisor (pemberi waralaba) dan franchisee (penerima waralaba) itu sendiri. Jadi apa yang dilakukan oleh franchisee harus sepengetahuan dan seijin franchisor.

Secara umum, sebagai sebuah media online, cnnindonesia.com belum berhasil melaksanakan kewajibannya sebagai media yang objektif dan netral karena faktor hanya mengandalkan satu pihak saja sebagai nara sumber. Begitu juga dengan unsur kelengkapan berita yang tidak semuanya terpenuhi. Dan sebaiknya sebagai media yang ada di Indonesia lebih bisa mendukung kegiatan yang ada di Indonesia terutama yang menyangkut kepentingan rakyat banyak, yang mana salah satunya adalah penyelenggaraan "Pilkada Serentak" yang pertama ini.

\section{KESIMPULAN}

1. Sebagai media online, CNNIndonesia.comkurang memperhatikan unsur kelengkapan berita $5 \mathrm{~W}+1 \mathrm{H}$, karena 3 (tiga) dari 5 (lima) berita yang dianalisis tidak memenuhi unsur how ( 2 berita) dan unsur why (1 berita). Walaupun mengandalkan kecepatan, namun sebagai media online tetap harus memperhatikan unsur kelengkapan berita tersebut.

2. CNNIndonesia.com hanya mengandalkan sumber dari satu pihak saja, bahkan ada 1 (satu) berita yang menuliskan pernyataan dari wartawan saja. Di sini unsur objektivitas dan kenetralan berita dipertanyakan, karena seharusnya informasi didapatkan dari berbagai pihak, terutama pihak-pihak yang bertentangan.

3. CNNIndonesia.com seolah kurang mendukung pelaksanaan "Pilkada Serentak", karena 4 (empat) dari 5 (lima) berita hanya menunjukkan sisi negatif dari pelaksanaan Pilkada ini. Padahal "Pilkada Serentak" ini merupakan kegiatan pertama kali diadakan di Indonesia dan berhubungan dengan kepentingan rakyat banyak.

4. Dalam mengkonstruksi pemberitaan mengenai "Pilkada Serentak" ini, CNNIndonesia.com tidak menunjukkan dukungan terhadap calon manapun maupun Partai Politik pengusung calon. Artinya CNNIndonesia tidak mempunyai kepentingan politis terhadap golongan (Partai Politik) tertentu.

\section{UCAPAN TERIMA KASIH}

Penulis menyampaikan rasa terima kasih yang sebesar-besarnya kepada seluruh pihak yang telah turut membantu dalam terlaksananya penelitian ini sampai selesai. Kemudian juga saya ucapkan terima kasih dan rasa hormat saya kepada tim redaksi Jurnal Communication Universitas Budi Luhur yang telah menerima artikel ini untuk dipublikasikan.

\section{DAFTAR PUSTAKA}

Bungin, Burhan. 2003.Analisis Data Penelitian Kualitatif: Pedoman Filosofi dan Metodologis ke arah Penguasaan Model Aplikasi.Jakarta: Raja Grafindo Persada. 
Eriyanto. 2001. Analisis Wacana: Pengantar Analisis Teks Media. Yogyakarta: LKIS Pelangi Aksara.

Eriyanto. 2007. Analisis Framing. Konstruksi, Ideologi, dan Politik Media. Yogyakarta: LKis Pelangi Aksara.

Mulyana, Deddy. 2003. Metodologi Penelitian Kualitatif: Paradigma Baru Ilmu Komunikasi dan Ilmu Sosial Lainnya. Cetakan Ketiga. Bandung: PT Remaja Rosdakarya.

Sobur, Alex Sobur. 2004. Analisis Teks Media Suatu Pengantar untuk Analisis Wacana, Analisis Semiotik, dan Analisis Framing. Bandung: PT. Remaja Rosdakarya.

https://id.wikipedia.org/wiki/CNN_Indonesia\#cite_note-1, diakses pada 3 Desember 2015, pukul 10.42 . 